\title{
Fees, flows and imaginaries: exploring the destination choices arising from intra- national student mobility
}

\author{
Allan Findlay, Helen Packwood, David McCollum, Glenna Nightingale \& Scott \\ Tindal
}

\section{ABSTRACT}

\begin{abstract}
Are intra-national student flows driven by the same forces as international student mobility? This paper addresses this question by analysing cross-border student mobility in the UK. The paper identifies four principles that one might expect to drive the destination choices of students from Scotland enrolling in English universities. Following a statistical analysis of student destination choices, it is argued that cross-border moves from Scotland to England are stimulated by some of the same global forces as international student mobility (such as a desire to accumulate cultural capital), but in terms of destination choice the imaginaries held by Scottish students of 'good' places to study in England to accumulate cultural capital are constructed differently from the imaginaries of international students.
\end{abstract}

KEYWORDS: Tuition fees, student mobility, cultural capital, destination choices, glocalisation

\section{Introduction}

International student mobility has received increasing attention from academics interested in its significance in the context of the globalisation of higher education (King and Ruiz-Gelices 2003; King et al. 2011; Brooks and Waters 2011; Waters 2012; Alberts and Hazen 2013; Raghuram 2013). Some have even suggested that there has been a glut of research on the topic (Bailey and Yeoh 2014). By contrast, there has been less interest in recent years in internal student migration or the movement between regions and within the regions of a state.

The aim of this paper is to ask whether the drivers of international student migration also apply to student mobility within a state. The international student mobility literature points to globalisation and the internationalisation of higher education as well as to the desire to build social and cultural capital as key drivers (King et al. 2010), while intra-national student mobility often emphasizes the importance of place and proximity to the parental home (Prazeres 2013; Holton 2015). An interesting twist offered by the current paper is the context of the research. This is set in the UK at a time when there has been a marked rise in the cost of student tuition fees for British students enrolled in one part of the state (England), but not in another (Scotland, where tuition is free). This has produced an extra reason to ask whether 
Scottish students selecting to study in England are behaving in a similar fashion to international students with respect to their mobility.

The paper seizes the opportunity to ask whether globalisation and 'glocalisation' effects (Faulconbridge and Beaverstock 2009) in higher education can be observed in relation to internal student migration (sometimes described as intra-state student mobility). By glocalisation, we mean the role of local context in understanding global processes (Guilianotti and Robertson 2014). In particular, the paper seeks to be original in probing the significance of 'where' students study. We ask about the importance of four dimensions of the 'geography' of student flows: distance from home, the destination location in terms of whether or not the place of study is a global city, the perceived excellence of the institution of study and finally the competitive aspects of place as represented in education landscapes by the composition of the student population.

This paper commences with a review of what might be expected to be the principles governing cross-border flows within the UK, before engaging in rigorous analysis of four hypotheses relating to the drivers of intra-national mobility using a national database that records student migration flows. We then offer a critical evaluation of why student interviewees explained their movements in a way that was not entirely compatible with the statistical evidence about student mobility. Finally, we seek to theorise the role both of fees and of student imaginaries of the meanings of their destination choices.

\section{Globalisation, glocalisation and the production of cross- border student flows in an uneven education landscape}

To introduce our research, the reader needs to understand two different literature: first, we briefly review some salient dimensions of research work on student mobility, both international and intra-national; and second, we summarise the context underpinning the UK's divergent HE policies across the country's four nations.

The research literature on international student migration has expanded very considerably in recent years (Brooks and Waters 2011; King and Raghuram 2013), reflecting not only the rapid global growth of the international student population but also the historically poor conceptualisation of this type of flow (neither adequately addressed by labour migration theory, nor by work on asylum seekers and refugees). Since the focus of this research paper is geographical, we restrict discussion to the key research themes relating to the factors shaping the destination patterns of student migrants, setting on one side the large issue of why young people choose to move and select to study at an institution close to home

Perhaps the natural geographical starting point is recognition of the highly uneven destination pattern of student migrants. This is true both between nation states and between higher education institutions within a country (King and Findlay 2012, 270). Since 1945, the USA has been the largest recipient of international students in absolute terms, whereas countries such as 
the UK and Australia have become evermore popular destinations with much higher proportions of international students relative to their domestic student population than other countries. This feature alone prompts the question of what is the relationship between international student flows and access to university places for domestic students (Tindal et al. 2015). Is the relationship a competitive or complementary one? In terms of engaging in social and economic processes, the spatiality of student flows sits at the interface between the globalisation of HE (Gulson and Syme 2007) and the glocalisation of intrastate and inter-state student flows (Tindal et al. 2015).

The uneven pattern of demand for access to study opportunities in particular countries, and at certain esteemed universities within these countries, has been conceptualised principally in two ways. First, following Bourdieu (1979), geographers such as Waters (2006) have argued that the search for educational distinction, attained through enrolment in elite national and international universities, explains the extraordinary geographical concentration of many international students in a small number of 'world-class' institutions (Findlay et al. 2012). This marker of distinction has been a key mechanism contributing to wider processes of reproducing class advantage (Bourdieu and Passeron 1990). This is achieved by separating these students from those only able to attend less prestigious local HEIs in the increasingly globally differentiated education system (Holdsworth 2009; Jöns and Hoyler 2013; Raghuram 2013).

Mavroudi and Warren (2013) and Jöns (2015) have argued that the patterning of student flows is set within a wider landscape of international knowledge flows (involving other movers such as academic staff, highly skilled workers, etc.) whose organisation also has ensured a globally uneven network of knowledge hubs. An important caveat to this is the imperfect match between the pattern of world-class universities and the much-researched patterning of global cities ( $\mathrm{Li}$ et al. 1996; Taylor 2004; Taylor, Hoyler and Evans 2008). Despite this, a recent study by Beech (2014) notes that international students coming to the UK report proximity to London (UK's leading global city) as a factor shaping their decision over where to locate.

A second way in which the uneven pattern of student mobility has been understood by geographers is through the production of higher education by those charged with supplying HE. On the onehand state actors, and on the other hand individual university stakeholders, compete in a globally uneven education market to position their HE brands in such a way as to attract particular types of students (Findlay 2011). Arguably, the states that were most active in 'selling' their higher education products in the first decade of the new millennium were Australia and the UK. More recently, other states have become very active in promoting their higher education systems in the global marketplace. As well as competing internationally, universities also compete with one another to attract domestic students, and this process has recently become more complex as a result of tuition fee differentials between institutions and between the four constituent parts of the UK.

Arguably, in recent years, there has been much less written by geographers on student migration within countries. Once again we set on one side research that has focussed on the decision of whether to leave the parental home and to enrol in a university in another part of 
country, a literature that confirms the tendency for students from economically and socially less fortunate backgrounds to study locally (David 2007; Holdsworth 2009; Mulder and Clark 2002). Instead, we focus on destination choices and inter-regional migration patterns. Given the aptitude of those with social power to use education to distinguish themselves and their children from others in society (Bourdieu 1979), it is not entirely surprising that widening HEI access has led to a search for new forms of educational distinction among students moving internally within the UK for education. Fotheringham et al. $(2004,1699)$ noted that as the number of places to study at university increased, so the volume of mobility amongst 16-19year-olds also rose, with localities hosting a larger number of university places experiencing higher in-migration rates for this cohort and with distance from parental domicile having a selective effect on destination choices. Although high levels of movement back and forwards between university, parental home and post-study work locations are characteristic of these mobilities, of even greater significance is the observation that inter-regional mobility of young adults has increased when other cohorts in the population appear recently to have become more rooted (Sage et al. 2013).

Geographers working on similar issues in the USA have also remarked on the influence of distance on intra-state student migration patterns, but have noted that the effect is differentiated by the type of HEI (Alm and Winters 2009). Ertl (2005) found similar patterns in Germany resulting from the uneven distribution of opportunities between east and west following the reunification of the country.

We turn now to the second key context of relevance to studying intra-state student migration in the UK: namely, the effect of differential fee regimes on the scale and nature of student flows. The parallels and differences between intra-state flow patterns of student migration in the UK, USA and Germany are very interesting, given the recent history in the UK of introducing increasingly differentiated HE systems between the four nations of the UK. In the USA, significant differences in university fee regimes exist at the institutional level with higher quality HEIs apparently able to charge higher fees and to attract students from distant parts of the USA (Baryla and Dotterweich 2001; Mak and Moncur 2003). In Germany, not only had the two parts of the country experienced over 40 years of separate educational development but following re-integration, there was an uneven introduction of higher fee levels. In Germany, the Länder that first introduced higher fees experienced some loss of students to other places, but the effect was small compared with the overall consequence of wider restructuring. The economic and social background of students was the main driver of selective student mobility towards what were perceived to be better universities (Reiner and Pollok 2010). Interestingly, all 16 German Länder had by 2014 moved to abolish student tuition fees again, in contrast to the situation in the USA and England and Wales.

In the UK, not only have Scotland and England maintained distinctive HE systems (for example, Scotland's four-year undergraduate degree compared with England's three-year degree), but there is also the financial divide. From 2004 onwards, UK students enrolled at English HEIs were charged $£ 3000$ in tuition fees. The cap on tuition fees rose progressively to $£ 9000$ by 2011 for first-year students enrolling in session 2012/13 and is set to widen further 
in the near future. Croxford and Raffe (2013) offer a detailed history of how Scotland followed a different route, favouring free education for Scottish-domiciled students, but charging fees for those coming from other parts of the UK. Johnston (2015), quoting the economist Robert Wright, has claimed that one consequence of this, in the context of limited university places, has been the tendency for highly ranked Scottish universities to accept fee-paying English students to the detriment of non-fee-paying Scottish students.

Researchers investigating the effect of fees on the volume of cross-border flows have noted very little change in the number of English-domiciled students heading north to Scotland to study, but the flow in the other direction has changed to some extent (Tindal et al. 2015). According to the UK's Higher Education Statistics Agency (HESA), the volume of first-year Scottish-domiciled students enrolling in English HEIs dropped by 21\% in 2012/13 compared to the previous year. Interestingly, the numbers in 2013/14 (the most recent year for which data is available) recovered to only $11 \%$ below the $2011 / 12$ level. The short-run effect of the introduction of fees, therefore, seems to have been quite small in terms of the volume of student mobility. Despite the tuition fee frontier, the rate of Scottish student out-migration to England remains higher than the rate of the English in-flows to Scottish HEIs. In the context of this paper, this context raises two interesting questions:

1. Why given the need to pay $£ 27,000$ for tuition fees to study in England, do so many Scots continue to migrate south?

2. Can the international student migration literature, with its pointers to the importance of cultural and symbolic capital, help explain the pattern of student destinations chosen by Scottish students?

Given the research literature, our expectations in answering these questions are summed up in four hypotheses:

First, the continuation of student flows from Scotland to England is not irrational economic behaviour, but reflects the significance of the cultural and symbolic capital to students from middle-class backgrounds who are motivated to enrol in so-called world-class universities.

Second, we hypothesize that cross-border flows from Scotland to England are akin to international flows in some other respects, leading to the expectations that the selectivity of Scottish students in their destination choices will be similar to students from outside the UK, for example, in relation to the 'lure of London' as a global city (King et al. 2014).

Third, we expect that the location of study will not only reflect the availability of university places, but that it will be inverse to the distance from the place of a student's parental domicile.

Fourth, we expect that competition for access to places of study will lead to a glocalisation effect with international and Scottish students being especially attracted to highly rated HEIs and with this resulting to some extent in the displacement of English students. 


\section{The search for evidence: methodological issues in understanding student flows}

To answer these questions, the paper draws on two very different kinds of evidence. First, it briefly explores the significance of paying fees as reported by Scottish students engaged in cross-border mobility. From interviews with students undertaken by the authors in 2014, we probe the relation between short-term financial outlay relative to the perceived longer term gains in cultural and symbolic capital. Second, the paper analyses secondary data on crossborder flows collected by the UK's HESA in order to analyse the pattern of movement. In this section of the paper, we offer a brief description of these two data sources, before considering how they can be used to offer insights that might not be achieved using only qualitative or quantitative evidence.

The selection of 25 students for an interview was guided by prior consideration of a 10-year run of HESA data relating to cross-border flows. This dataset identifies a student's place of normal domicile and their location of study. To qualify as a cross-border mover for our interviews, someone had to have resided for five years or longer in Scotland or England, respectively, before moving to enrol for study in a higher education institution in another part of the UK. This five-year window is the time span which defines the right of British citizens resident in Scotland to receive free tuition at a Scottish university. HESA data led us to purposively seek cross-border migrants from a range of 11 universities which we believed would reflect the diverse drivers underpinning recent flows (in terms of subjects studied and destinations selected). We targeted first- and second-year undergraduates to capture recent student mobility in relation to the introduction of differential fee regimes north and south of the border.

Being critically reflexive, we recognise that our interviews did not include students who were immobile (thus excluding the voices of young people who for financial or other reasons felt unable - or did not desire - to enrol at a university outside their country of normal domicile). Thus, our study does not claim to offer insights about movers relative to non-movers, but rather to focus on deepening understanding of destination choices amongst those students who were able to make a cross-border move. Others have already made valuable contributions in researching the experiences of students who study in a university close to their place of normal domicile (Holdsworth 2009; Holton 2015). The selectivity of student mobility means that it is not surprising that our interviewees were young (the majority were between 18 and 22 years of age) and disproportionately more likely to be from better-off middle-class households ( $84 \%$ of interviewees had at least one parent with a university degree and $80 \%$ had a parent whose occupation would be classified as from groups 1 or 2 of the ONS socio-economic classification as the two highest socio-economic classes). The transcripts from the interviews were investigated using NVivo software. In this paper, the theme of student fees was interrogated using a sign, signified, signifier analytic frame (Shubin et al. 2014) to discover the different meanings associated with the payment of fees. The analysis of the transcripts then progressed to other features of student mobility that the research literature had pointed us to as of potential 
significance, including imaginaries around the cultural and symbolic capital to be gained by enrolling in so-called world-class universities, and from studying in some locations such as global cities rather than in other places.

Some further details of the wider project are reported elsewhere (Tindal et al. 2015). Below, we report only the methodological details pertinent to achieving the aim of the research reported in this paper, as established in the Introductory section. In Tindal et al. (2015), quotations from the same round of interviews were used to deepen understanding of cultural capital arguments. The section of the interviews relating to fees and the financing of higher education were not touched on in our earlier paper. In this paper, unlike Tindal et al. (2015), the interview excerpts are taken only from Scottish students enrolled in English universities. Student voices have been given pseudonyms, although we have indicated the real-life discipline choices of the students. Readers might wish to refer to Tindal et al. (2015) if they want to discover why it is necessary to go beyond Bourdieu (1979) to achieve a fuller understanding of the geography of cultural capital as a driver of student migration (an issue not rehearsed once again in this paper).

The main evidence base on which this paper rests is a rigorous statistical analysis of secondary data using the UK's annual HESA. This dataset reports students' normal domicile and student place of study as well as other salient variables and the UK's uneven educational landscape. The HESA dataset is used to interrogate the key drivers underpinning student choices about where to enrol for their higher education. By using 2013/14 HESA statistics (HESA 2015) disaggregated by the university, we were able to examine the correlations between the places of enrolment of Scottish- domiciled students, relative to the destination choices of English, EU and other international students. Information about the academic standing of universities was derived from the Times Higher University rankings, while the location of universities was evaluated relative, first to their location either within or outside the UK's global city, London, and second relative to their travel distance from Scotland. The statistical distribution of all variables was explored and $\log$ transformations were included where appropriate. A least squares multiple regression model was used to discover the level of variance explained by the independent variables.

Before turning to the statistical evidence, we explore what can be learned from the interview transcripts about why Scottish students move to England at all, and in particular, we probe the role of fee differentials in their decision to engage in cross-border mobility.

\section{'Don't base your decision on money'}

Rosie captures the dominant sentiment of most middle-class Scottish students in relation her discussion with her parents about paying tuition fees to study in England. Before choosing to study at an English university, she remembers: 
My parents said that, when I am applying 'we don't want it to be an issue.

Don't base your decision on money. ... We will work out how we are going to finance it afterwards. (Rosie, Scottish medical student, English university)

A similar comment was made by Toby:

My parents were kind of - they made it clear that they were happy to fund me, to some extent, if this is what I wanted to do. If I was serious about it, then they would be happy to give me the money. (Scottish science student, English university)

Student commentaries on issues of cost nearly always referred to parental discussions on the issue. Time and again the children of middle-class professional families reported being encouraged to leave the financial concerns to their family who would 'work out how' to cover the cost. Indeed, Rosie reported the complete lack of a financial constraint stating that 'Dad said "go wherever you want"' going on with unintended irony to say: "No one tried to influence my decision'.

Similarly, Fraser noted 'My dad agreed with me that making a longer-term investment for the future into an institution which has prestige above that of Scottish institutions' was what mattered, and 'I did not like the idea of money and the loan limiting what I wanted to do' (Fraser, Scottish social science student, English university).

We see again the importance of the family sphere here, with our interviewees' narratives being compatible with Bourdieu and Passeron's (1990) perspective on the social reproduction of advantage through 'investment' in the education of the next generation. Fees were interpreted therefore as signifying an 'investment for the future' rather than a short-term 'cost' paid for access to the commodity of higher education. Of course, this viewpoint would only be expressed by those with the economic capital to make this decision. Other researchers have shown how students from other backgrounds might not even have a discussion with their parents and if they did then the interaction would be likely to discourage from crossing the border and positively encourage them to live at home (Christie 2007; Holdsworth 2009).

To say that fees were represented as an investment does not mean that a rationalisation of the financial considerations of paying fees did not take place. Part of this was the relative cost relative to previous investments in the credentials offered by private secondary education. Isla notes:

For me the $£ 9000$ wasn't such as a shock because I (had) been to an independent school and, you know, I've seen those figures around. (Scottish science student at an English university)

Fees were not, therefore, a barrier to mobility for the group of students whom we interviewed. This is not to say that fees were not a constraint to other students, especially to those from lower income households, who for financial reasons decided to study in the country of their normal domicile. For those from more fortunate backgrounds, however, we see flows in both 
directions across the border, including Rosie from Scotland studying medicine in England and Gemma from England enrolled on a medical course in Scotland. This raises the interesting question of whether these exchange flows only reflect the diverse personal preferences of our interviewees or whether the flows reflect something more profound about the symbolic value of venturing far from home.

The financial calculus repeated time and again was that fees signified an 'investment' that would yield long-term returns because 'a good university' would more than compensate over time, through building social and cultural capital that would produce good returns over the life course. Table 1 reveals the codifying of fees as a financial lever privileging access to the 'best' university education.

\section{Table 1. The (in)significance of tuition fees.}

[Table 1 appears here]

Given the discourse around tuition fees, it is reasonable to surmise that student flows from Scotland to England can be expected to continue in the foreseeable future because the Scottish middle class (like those in other parts of the world) have identified this as a way to reproduce social advantage. It is interesting to note that the statistical evidence shows that following the introduction of the fee differential between Scotland and England, there was a small reduction in 2012/13 in Scottish cross-border flows. Thereafter, levels of movement rose once again.

The 'best' education, although rationalised by some in terms of seeking long-term financial returns through higher salaries accrued later in life, was also reported by Scottish students as being about opening up better opportunities for later national and international occupational mobility. For example, Toby, quoted earlier, interpreted his decision to move from Scotland to a leading English university as a key part of his longer term strategy to work in the USA. Fraser, a Scottish social science student at an English university, when asked about how his student mobility related to his career ambitions, expressed the subjectivities that he associated with studying in another part of the UK compared with staying in Scotland:

I suspect that had I gone to a Scottish university, I think I would still be saying 'civil service' ... 'Scottish students staying in Scotland' maybe limits your view as to what career paths you can take, but yeah - ... I'll almost certainly stay in London ... the sort of careers and stuff that I'm looking at ... are all in London. (Scottish social science student, English university)

In summary, students voiced the perception of fees not as a cost, but as an investment, and they explained their study destination choices in terms of imagined geographies relating to which universities were world class and which locations offered the best opportunities to launch a future international career. This 'global futures' dimension is a feature of student mobilities that some other research studies (King et al. 2014; Tindal et al. 2015) have identified as important. From the perspective of the core interest of this paper, it also illustrates a potential 
feature of 'glocalisation': namely, it raises the prospect that students may seek to access the global labour market without enrolling for international study, but through engaging in longdistance student migration to a university located in a global city or in a location with a global reputation located within the nation state of their birth.

\section{Triangulating voices and numbers - a statistical perspective on cross-border student flows}

The qualitative evidence provided so far by student voices builds a picture that is not incompatible with the view that cultural and symbolic capital gained through student migration more than offsets the financial outlay facing Scottish students in paying higher fees to cross the border to study in England. Moreover, there is a hint that the geography of cultural capital accumulation, which students imagined could be achieved through their mobility, was shaped not only by the academic rankings of universities but by other imaginaries. These included imaginaries about locations where 'the building of relationships' with the right people could take place (the search for social capital and a certain 'habitus'), or locations such as London that have global economic significance, thus linking to arguments about the interplay between global cities and global citizenship (Lewin 2010).

We now seek to triangulate these ideas with the statistical evidence. We selected the flow of first-year students in 2013/14 (Scottish-domiciled students enrolled at English HEIs) as the dependent variable. Figure 1 maps the variable, showing the destination pattern of Scottish cross-border flows to England. Popular destinations include HEIs in Northern England as well Cambridge, Oxford and London.

The independent variables in the regression model are defined in Table 2. Table 3 shows the regression coefficient resulting from running a range of models using different combinations of variables.

The first column of Table 3 represents the zero-order model where the statistical power of each of the variables is shown individually relative to the variation in the number of Scottish firstyear students. In the other columns to the right of the table, different combinations of variables are entered in a series of multiple regression models. The zero-order correlations show that at $p=.001$, distance from Scotland and world university ranking were the most powerful covariates, with less significant associations also evident between Scottish student numbers and the size of the first-year English student body $(p>.01)$, the number of first-year students from other EU countries $(p>.01)$ and other international students from outside the EU $(p>.05)$. There was no statistical association between student migration and the location of study being London.

Model 2 tests a traditional gravity model formulation, namely that the flow of Scots first-year students to English universities in 2013/14 was inverse to distance (log) and proportional to the size of the enrolled student population (English-domiciled, European and other international 
students). This model is surprisingly persuasive in statistical terms accounting for about a third of all variance. It underscores the importance for geographers (and others) of not overlooking the power of long-established regularities. In the context of student migration, this tells us that the number of study opportunities and their proximity to the place of origin of the student migrant population remain a major factor in accounting for the patterning of the flow. To some extent, the absence of many university study opportunities in southern Scotland (Dumfries campus of Glasgow University being the main exception) may also help explain the presence of the high volume of short-distance cross-border flows from Scotland to Cumbria, Newcastle and Northumbria universities. The analysis also shows that the pattern of study opportunities in England is uneven in terms of who studies where. Finally, it should be noted that in terms of the pattern of places of study that Scottish students accessed in England, this model appears to show a much stronger association with English and 'other international' students than with EU students.

\section{Figure 1. Intra-national student flows from Scotland to England.}

\section{Table 2. Definition of variables used in the authors' regression analysis.}

[Table 2 appears here]

\section{Table 3. Regression coefficients for five models in relation to the flow of first- year Scottish students to English universities (2013/14).}

[Table 3 appears here]

Model 3 considers only distance effects and university rankings. Following cultural and symbolic capital arguments (Brooks and Waters 2011), the model confirms a strong association and confirms that a key element in the selective nature of Scottish student mobility to English universities is the search for world-class places to study. The statistical analysis could support the thesis that Scottish cross-border movers are driven by similar forces to those governing international students. Useful as this position might seem to be in relation to cultural capital perspectives on student migration (Brooks and Waters 2011), it is worth noting that this statistical model is less powerful in explaining variance in the destination patterns than the gravity formulation of Model 2.

Model 4 makes a simple addition to Model 3 by including the possibility that study in a global city might constitute a different type of distinction and offer a little extra explanation to the cultural capital model. Given the results of the zero-order regression, it is not surprising to find that this model does not add significant extra explanatory power. It does, however, raise interesting questions about how to interpret the qualitative research on cosmopolitanism and global cities quoted earlier in this paper.

Finally, Model 5 offers what we term the glocalisation model, including all the variables from Models 2 to 4. A more parsimonious version of the model could exclude those variables found not to be significant in the earlier calculations, with the effect of raising the overall adjusted $R^{2}$ 
value. However, Model 5 as it stands explains $48 \%$ of all variance and offers a significantly more powerful statistical account of variations in Scottish first-year student mobility than any of the other models, and allows us to evaluate the significance of all the variables discussed so far.

Model 5 supports the view that the distance from Scotland, the world ranking of universities and the attraction of these universities to English and European Union students all contribute very significantly to explaining the number of Scottish students enrolled in English HEIs. Distance (a 'local' as opposed to a 'glocal' effect) remains the most statistically powerful independent variable. University ranking is the next most powerful influence confirming the attraction of Oxbridge and other influential universities in attracting Scottish students south. To the authors, what is especially interesting in model 5 are the other variables that seem to offer explanation once the effects of distance and cultural capital are accounted for. Interestingly, the presence of international students (from outside the EU) offers no additional explanatory power, but the presence of English and EU students do. It is perhaps logical, with the hindsight offered by the final model, that Scottish students are more like EU students than any other student group. Scots and EU both pay the same tuition fees at English HEIs (unlike other international students), while at least some English students have lower subsistence costs than Scots because a proportion live at their parental address. Finally, it should be noted that the coefficient shows a positive association between the English and Scottish patterns (rather than a negative one), ruling out the displacement hypothesis.

\section{Discussion and conclusions}

The aim of this paper was to ask whether the drivers of international student migration also apply to student mobility within a state. This aim was addressed through establishing four specific hypotheses about how the drivers of international student mobility might be expected to operate in the context of intra-national moves from Scotland to England.

First, we anticipated a continuation of student flows from Scotland to England because we expected Bourdieu's understanding of the power of educational 'distinction' to trump the economic rationale of students selecting to study in the least expensive location. Both the interviews and the modelling exercise upheld this finding, with the interviews adding extra value by revealing how fees and the extra cost of studying in England were signified by Scottish students. Fees were represented as an investment set against the long-term cultural capital accrual.

Second, we suggested that Scottish students enrolled in English universities would be like European and other international students in some respects. The evidence was mixed. Some of our interviewees from London-based universities espoused the value of life experience in a global city, noting the advantage this might be for later career development as global citizens and employees of transnational corporations, a message reported by Tindal et al. (2015). However, the modelling of HESA data showed that there was no statistically significant association between being a Scottish student and enrolling in a London-based college. From 
this, we conclude that not only was there no evidence of additional cultural capital being accrued from studying in London (over and above the standing of its universities [Model 4]), but that unlike international students London was not disproportionately attractive to Scottish students after its size is taken into account (Model 5). Indeed, our research findings would seem to be compatible with and extend the research of Taylor, Hoyler and Evans (2008) that noted the 'company town effect' of prestigious universities in smaller centres. Our work might add to this the greater opportunities for habitus that might be found in smaller centres such as Oxford, Cambridge or St Andrews where higher education not only has a dominant effect on the local labour market but also on local society.

Third, we expected locations of study would not only reflect the availability of university places but also would be inverse to the distance from the place of a student's parental domicile. The confirmation of these relationships by the statistical modelling did not surprise us, but the strength of the relationship was remarkable accounting for more variance than other factors. The geographical research literature has recently said very little about 'distance' at a time when geographers have become much more interested in social and cultural constructions. Beech (2014) is, of course, an exception in her treatment of 'distance from London' as a key driver of the imagination of international student migration choices, but in the case of Scottish students in England, the explanatory power of distance from Scotland is more difficult to resolve. Few of the interviewees specifically volunteered comments on the matter, although some did attest to the desire to follow certain highly valued professional courses. For these students, achieving the distinction of entry to a particular degree such as medicine or veterinary science was undoubtedly an important stimulant to migrate. Some students who had failed to gain entry to these much sought after degrees at Scottish universities then accepted places at a nearby English university. This explanation chimes in some ways with Brooks and Waters' (2009) research on international students seeking a second chance of success. These findings are substantiated to some extent by Tindal et al. (2015) who note the desire to access medical and vet school places as another key driver of shorter distance inter-regional student migration.

Fourth, we expected that competition for access to places to study at world-class universities might result in a 'glocalisation' effect, involving the attraction of highly rated institutions to international and Scottish students and resulting in some displacement of some English students. The statistical modelling presented in Table 3 leads us to reject this idea. Model 1 showed a positive association between the locations of the study of Scottish and English students and a weak inverse association between where Scottish students and international students from outside the EU. The research seems to uphold the proposition that Scottish students migrating to England are much more like their southern counterparts in the drive to reproduce class 'distinction' through enrolling in the most prestigious universities and seeking access to specialised professional courses. The imaginaries of 'good' places to study in England, as constructed by Scottish students, do not mirror the imaginaries of international students from outside the UK.

This paper has sought a deepening of understanding of how the global interacts with local in the context of intra-national student mobility. The unevenness of the educational landscape 
resulting from the globalisation of HE seems to have affected the geography of where Scottish students seek to enrol in England. For some, this has indeed been an opportunity to access 'world-class universities'. This has not, however, been the only driver. Glocalisation effects have been shown to be complex and it has not been possible to conclude from our work that global cities are a special attractor to intra-state student movers in the same way as they are to international migrants. Nor do our findings reveal glocalisation in terms of the expected competitive relations between local students (English), intra-state migrants (Scottish students) and international students. This is highly significant in both conceptual and policy terms. It is not to say that glocalisation effects do not exist. On the contrary, our research points to the need for educational providers and policy-makers to recognise that although intra-national and international student flows are both affected by global forces, they are sometimes affected at the local level in rather different ways.

\section{Acknowledgements}

We are very grateful to Heike Jöns for drawing my attention to this interesting contrast. We are indebted to Ian Shuttleworth for this point.

\section{Disclosure statement}

No potential conflict of interest was reported by the author.

\section{Funding}

This research was undertaken within a wider research programme financed by ESRC grant ES/G027153/1.

\section{References}

Alberts, H., and H. Hazen, eds. 2013. International Students and Scholars in the United States. New York: Palgrave Macmillan.

Alm, J., and J. V. Winters. 2009. "Distance and Intra-State College Student Migration." Economics of Education Review 28: 728-738. doi: 10.1016/j.econedurev.2009.06.008

Bailey, A. J., and B. S. A. Yeoh. 2014. "Migration, Society and Globalisation: Introduction to Virtual Issue." Transactions of the Institute of British Geographers 39: 470-475. doi: $10.1111 /$ tran. 12056

Baryla, E. A., and D. Dotterweich. 2001. "Student Migration: Do Significant Factors Vary by Region?” Education Economics 9: 269-280. doi: 10.1080/09645290110086135

Beech, S. E. 2014. "Why Place Matters: Imaginative Geography and International Student Mobility." Area 46: 170-177. doi: 10.1111/area.12096

Bourdieu, P. 1979. Distinction. London: Routledge. 
Bourdieu, P., and J. C. Passeron. 1990. Reproduction in Education, Society and Culture. London: Sage Publications.

Brooks, R., and J. Waters. 2009. “A Second Chance at 'Success'.” Sociology 43: 1085-1102. doi: $10.1177 / 0038038509345713$

Brooks, R., and J. Waters. 2011. Student Mobilities, Migration and the Internationalization of Higher Education. Basingstoke: Palgrave Macmillan.

Christie, H. 2007. "Higher Education and Spatial (Im)Mobility: Nontraditional Students and Living at Home." Environment and Planning A 39: 2445-2463. doi: 10.1068/a38361

Croxford, L., and D. Raffe. 2013. "Differentiation and Social Segregation of UK Higher Education, 1996-2010." Oxford Review of Education 39: 172-192. doi: $10.1080 / 03054985.2013 .784193$

David, M. E. 2007. "Equity and Diversity: Towards a Sociology of Higher Education for the Twenty-first Century?" British Journal of Sociology of Education 28: 675-690. doi: $10.1080 / 01425690701505664$

Ertl, H. 2005. "Higher Education in Germany: A Case of 'Uneven' Expansion?" Higher Education Quarterly 59: 205-229. doi: 10.1111/j.1468-2273.2005.00292.x

Faulconbridge, J., and J. Beaverstock. 2009. "Globalization.” In Concepts in Geography, edited by N. Clifford, S. L. Holloway, S. P. Rice, and G. Valentine, 331-343. London: Sage.

Findlay, A. M. 2011. "An Assessment of Supply and Demand-side Theorizations of International Student Mobility." International Migration 49: 162-190. doi: 10.1111/j.14682435.2010.00643.x

Findlay, A. M., R. King, F. M. Smith, A. Geddes, and R. Skeldon. 2012. "World Class? An Investigation of Globalisation, Difference and International Student Mobility." Transactions of the Institute of British Geographers 37: 118-131. doi: 10.1111/j.1475-5661.2011.00454.x

Fotheringham, A. S., P. Rees, T. Champion, S. Kalogirou, and A. R. Tremayne. 2004. "The Development of a Migration Model for England and Wales: Overview and Modelling Outmigration." Environment and Planning A, 36: 1633-1672. doi: 10.1068/a36136

Guilianotti, R., and R. Robertson. 2014. "Sport and Globalisation." In A Companion to Sport, edited by D. Andrews and B. Carrington, 41-60. Oxford: Wiley-Blackwell.

Gulson, K., and C. Syme. 2007. "Knowing One's Place.” In Spatial Theories of Education, edited by K. Gulson and C. Symes, 1-16. London: Routledge.

HESA (Higher Education Statistics Agency). 2015. Higher Education Statistics for the UK 2013/14. London: HESA.

Holdsworth, C. 2009. "Between Two Worlds: Local Students in Higher Education and 'Scouse'/Student Identities." Population, Space and Place 15: 225-237. doi: 10.1002/psp.511 
Holton, M. 2015. “'I Already Know the City, I Don't Have to Explore it': Adjustments to 'Sense of Place' for 'Local' UK University Students." Population, Space and Place 21: 820 831. doi: 10.1002/psp.1866

Johnston, S. 2015. "Scots Students Losing out on University Places to EU students." The Telegraph, 22 February 2015.

Jöns, H. 2015. “Talent Mobility and the Shifting Geographies of Latourian Knowledge

Hubs.” Population, Space and Place 21: 372-389. doi: 10.1002/psp.1878

Jöns, H., and M. Hoyler. 2013. "Global Geographies of Higher Education: The Perspective of World University Rankings.” Geoforum 46: 45. 59. doi: 10.1016/j.geoforum.2012.12.014

King, R., and A. Findlay. 2012. "Student Migration.” In An Introduction to International Migration Studies, edited by M. Martinello and J. Rath, 259-280. Amsterdam: Amserdam University Press.

King, R., A. M. Findlay, and J. Ahrens, 2010. International Student Mobility Literature Review. London: HEFCE.

King, R., A. M. Findlay, J. Ahrens, and M. Dunne. 2011. "Reproducing Advantage: The Perspective of English School Leavers on Studying Abroad." Globalisation, Societies and Education 9: 161-181. doi: 10.1080/14767724.2011.577307

King, R., A. Lulle, F. Conti, D. Mueller, G. Scotto. 2014. The Lure of London: A Comparative Study of Recent Graduate Migration from Germany, Italy and Latvia. Brighton: Sussex Centre for Migration Research Working Paper 75.

King, R., and P. Raghuram. 2013. "International Student Migration: Mapping the Field and New Research Agendas.” Population, Space and Place 19: 127-137. doi: 10.1002/psp.1746

King, R., and E. Ruiz-Gelices. 2003. "International Student Migration and the European 'Year Abroad'." International Journal of Population Geography 9: 161-181.

Lewin, R. 2010. The Handbook of Practice and Research in Study Abroad. New York: Routledge.

Li, F. L. N., A. M. Findlay, A. J. Jowett, and R. Skeldon. 1996. "Migrating to Learn and Learning to Migrate: A Study of the Experiences and Intentions of International Student Migrants." International Journal of Population Geography 2: 51-67. doi: 10.1002/(SICI)1099-1220(199603)2:1<51::AID-IJPG17>3.0.CO;2-B

Mak, J., and J. E. T. Moncur. 2003. "Interstate Migration of College Freshmen." The Annals of Regional Science 37: 603-612. doi: 10.1007/s00168-003-0130-4

Mavroudi, E., and A. Warren. 2013. "Highly Skilled Migration and the Negotiation of Immigration Policy: Non-EEA Postgraduate students and Academic Staff at English Universities." Geoforum 44: 261-270. doi: 10.1016/j.geoforum.2012.08.008 
Mulder, C. H., and W. A. V. Clark. 2002. "Leaving Home for College and Gaining Independence." Environment and Planning A 34: 981-999. doi: 10.1068/a34149

Prazeres, L. 2013. "International and Intra-national Student Mobility: Trends, Motivations and Identity." Geography Compass 7: 804-820. doi: 10.1111/gec3.12080

Raghuram, P. 2013. "Theorising the Spaces of Student Migration." Population, Space and Place 19: 138-154. doi: 10.1002/psp.1747

Reiner, D., and R. Pollok. 2010. "Educational Expansion and Its Consequences for Vertical and Horizontal Inequalities in Access to Higher Education in West Germany." European Sociological Review 26: 415-430. doi: 10.1093/esr/jcp029

Sage, J., M. Evandrou, and J. Falkingham 2013. “Onwards or Homewards?” Population, Space and Place 19: 738-755.

Shubin, S., A. M. Findlay, and D. McCollum. 2014. "Imaginaries of the Ideal Migrant Worker: A Lacanian Interpretation." Environment and Planning D: Society and Space 32: 466-483. doi: 10.1068/d22212

Taylor, P. J. 2004. World City Network. London: Routledge.

Taylor, P. J., M. Hoyler, and D. M. Evans. 2008. "A Geohistorical Study of 'The Rise of Modern Science': Mapping Scientific Practice Through Urban Networks, 1500-1900." Minerva 46: 391-410. doi: 10.1007/s11024-008-9109-8

Tindal, S., H. Packwood, A. M. Findlay, S. Leahy, and D. McCollum. 2015. "In What Sense 'Distinctive'? The Search for Distinction Amongst Cross-border Student Migrants in the UK" Geoforum 64: 90-99. doi: 10.1016/j.geoforum.2015.06.001

Waters, J. 2006. "Geographies of Cultural Capital: Education, International Migration and Family Strategies Between Hong Kong and Canada." Transactions of the Institute of British Geographers 31: 179-192. doi: 10.1111/j.1475-5661.2006.00202.x

Waters, J. 2012. "Geographies of International Education: Mobilities and the Reproduction of Social (Dis)advantage.” Geography Compass 6: 123-136. doi: 10.1111/j.17498198.2011.00473.x 